\title{
Uncovering the Identity Conditions of High School Students
}

\author{
Gusti Rahayu'1, Herman Nirwana ${ }^{2}$, Netrawati ${ }^{3}$ \\ 1,2,3 Universitas Negeri Padang \\ *Corresponding author, e-mail: gustirahayu233@gmail.com
}

\begin{abstract}
This study aims to analyze the identity of high school students based on four levels of status (identity diffusion, identity foreclosure, identity moratorium, and identity achievement). Selfidentity is very important because the task of development at that time is to adapt to changes that exist in oneself. Teens who experience an identity crisis show that they are trying to find their identity. Therefore, adolescents need help to improve their identity. This study aims to describe the identity of students. The sample in this study consisted of 240 high school students who were selected by proportional random sampling. The instrument used was a self-identity scale. The instrument used has been tested for validity and reliability. Data analysis in this study used a quantitative approach with descriptive methods. The results showed that identity diffusion was in the high category 33.85 (81 students), identity foreclosure was in the high category $10.8 \%$ (26 students), identity moratorium was in the high category $46.2 \%$ (111 students), and identity achievement was at high category $9.3 \%$ (22 students). The implication of this research is the counselor's basis for improving the self-identity of students in schools.
\end{abstract}

Keywords: Information Services, Self-Identity

How to Cite: Rahayu, G., Nirwana, H., Netrawati, N. (2020). Uncovering the Identity Conditions of High School Students. International Journal of Applied Counseling and Social Sciences, 2 (1): pp. 27-33, DOI: https://doi.org/10.24036/005391ijaccs

\section{Introduction}

"Identity" is a general term used by social science to describe the conception and expression of a person's individuality and identity is also a source of meaning for a person (Bailey, 2003). The concept of personal identity according to Glas (2006), it is divided into two forms, namely identity as a singularity (numeric identity) and identity as a series of qualities that allow individuals to identify as a certain group of individuals (qualitative identity). Hibbert argues that the need for personal identity can influence a person's behavior and identity plays an important role in making decisions (Wang, Wu \& Lee 2018). Owens argues that personal identity reflects traits or characteristics that may be felt apart from a person's social identity or role associated with all identities that exist in him (Oyserman, Elmore \& Smith, 2012). Polkinghorne argues that identity is not something that is formed with just one form but is continuous during life (Breen, 2010). According to Jaussi, Randel \& Dionne, identity is formed over time (Nealy, 2013) without any compulsion. Furthermore, according to Cinoglu \& Arikan (2012), the self is the main figure in the process of forming an identity. The individual must also learn or recognize sociology and social psychology that exist in himself. 
In social psychology, self-identity is an expression for a psychological experience (thoughts, feelings, motives, etc.) that reflects and affects somoone's understanding of the social world (Simon \& Trotschel, 2008). Self-identity is the process of becoming a unique individual with an important role in his life (Papalia \& Feldman, 2001). According to Owens (2003), self is a process and self-organization that is born from reflection while identity is a tool (strategy) of individuals or groups in categorizing themselves and how they present themselves to the world. Self-identity is the perspective that a person takes towards himself in taking a special role, combining meanings and expectations related to what is inside him, thus forming identity standards that guide behavior that is relevant to identity (Rise, Sheeran \& Hukkelberg, 2010). Self-identity is an individual's awareness of who he is, which consists of self-characteristics, determining important and proper things to do, as well as standards in evaluating his actions and behavior, which are integrated in himself so that he feels he has a unique and different personality from other individuals. Waterman (Chen, Lay, Wu \& Yao, 2007) argues that self-identity is a self-definition that is clearly delineated consisting of goals, values and beliefs possessed by someone who is firmly committed. Then, according to Weedon (Boonchum, 2009), identity can help someone understand themselves and others deeply, not only in the form of ideas but also thoughts. Dan Erikson (Mansfield, Gill \& Golander, 2006) describes self-identity as a characteristic that determines who he is and where he goes. In line with that, Weinreich (Bridget and Kriner, 2016) in the psychological sense of identity described identity as the way a person interprets oneself constructively from the past to the future. Self-identity is a complex multidimensional concept with several components, namely who I am and what makes me different from other people (Bailey, 2003). Self-identity is directly related to behavior which can represent different roles for each individual in the social structure. This is in line with the opinion of Conner \& McMillan (Fekadu \& Kraf, 2001) that self-identity can be defined as a prominent part of a person's self-concept related to their behavior. Part of self-identity is formed by roles that are considered to come from oneself and one of these roles is the student (Bridget and Kriner, 2016).

According to Dariyo (2004), adolescents who have an identity crisis mean that they are showing that they are trying to find their identity. If the identity crisis can be resolved properly, the identity will be achieved optimally to achieve psychosocial well-being. Meanwhile, adolescents who are unable to resolve their identity crisis will experience identity confusion which is marked by feelings of inadequacy, helplessness, decreased self-esteem, insecurity which results in adolescents feeling pessimistic about their future. Confusion or loss of direction can result in two things, namely individuals will withdraw and isolate themselves from friends and family or immerse themselves in social settings so that they lose their identity in the crowd (Santrock, 2007). In line with the opinion of Hsieh, Hsiao, Yang \& Lee (2019), individuals with self-identity confusion have difficulty in accepting themselves. And Gullan (Ross, Powell \& Henriksen, 2016) adolescents who do not make it through the cycle of psychosocial development, adolescents will experience conflict with themselves and have difficulty living the next stage of life. Prasasti (2017) also states that adolescents who fail to find self-identity are identical with deviant behavior called juvenile delinquency which society does not accept or dislike (Berdibayeva, Ivanov, Satybaldina, Smatova \& Yeluayeva, 2016). Therefore, adolescents must be able to find what they believe, their ideal attitudes and values, which can play a role in their social life. One of the places where teenagers get an identity is at school. Therefore, all school parties participate and need to understand the experiences and developments in the process of forming youth identity in realizing a better future (Flum \& Kaplan, 2012).

This was supported by the results of a research conducted by Guneri, Sumer \& Yildirim (1999) on "Sources of self-identity among Turkish adolescents" of three male and three female students of senior high school in Ankara Turkey, which adolescents still have difficulties and confusion during the process of establishing identity. Many sources of self-identity among Turkish youths should be further explored and their contribution to the attainment of a healthy identity must be strengthened. Furthermore, a research was conducted by Situngkir (2014) about "The effect of providing information services in the 
social sector on the handling of identity crises in students". The results of this research proved that there is a significant effect of providing social information services on the handling of identity crises in students with an average pre-test score of 65.52 with a standard deviation of 267.12, while the average post-test result is 60.15 with a standard deviation of 200.43. Then, Syarqawi (2015) also conducted research on "Student identity and its implications in BK services". The results of the study proved that $84(50 \%)$ of the 164 respondents studied really need BK services to find their potential. This was evidenced by the intellectual self-identity data which is in the sufficient category with an average percentage, $54.07 \%$, and the indicators of religious spiritual self-identity and deity are in the sufficient category with a mean percentage, $66.6 \%$. Therefore, BK services can help students recognize all the potential that exists in them. Moreover, a study conducted by Masyita (2018) also proved that information services have a significant effect on students' abilities in overcoming self-identity crises which are marked by changes after being provided with information services, with an average pre-test score of the control group 77.88 while the average group post -test 81.31 . It means that the mean score of the experimental group after being provided with information services was higher than the mean score of the control group who was not provided with information services.

From several studies that have been conducted, it was proven that information services have a significant effect on helping students overcome the identity crisis. This assistance is provided by the school counselor / counselor, especially in providing information services related to personal identity. The counselor is an educator who plays a role in helping students overcome obstacles or problems and develop the potential that students have in school. Information services aim to equip individuals with the various kinds of knowledge needed to identify themselves, plan and develop life as students, family members and communities. This is in line with the opinion of Alizamar, Afdal \& Ifdil (2017) which stated that Guidance and Counseling is a part of education in schools that plays an important role in realizing students who are independent and develop optimally through services that are owned by one of the services that can be provided by BK teachers / counselors, namely information services.

Before providing information services, the counselor needs to make a systematic, well-organized and coordinated design within a certain period of time. The design must also be in accordance with the needs of students, so that the objectives of these services can be achieved optimally. The design of information services is made into a specific guide according to the needs of students and in it discusses aspects of self-identity (Tarigan, 2009). Not limited to providing service materials about personal identity, information services are intended to equip students with a wide range of knowledge and understanding about personal, social, learning and career. The knowledge and understanding referred to in this research is to solve the problems faced with regard to self-identity. And the information provided needs to be ensured that the service participants understand it or not. So, counselors need valid and reliable instruments to identify how high school students are.

\section{Method}

This study uses a quantitative approach with descriptive methods that describe systematically, factually, and accurately which describes the phenomenon in detail. The sample in this study consisted of 240 high school students who were randomly selected or proportional random sampling. The data collection technique used was a questionnaire instrument using a Likert scale model. The questionnaire was developed based on sub-variables consisting of identity diffusion, identity foreclosure, identity moratorium, and identity achievement. The data obtained were analyzed using the percentage technique from Sudjana (2002), where the percentage technique is the result of dividing the frequency with the sample then multiplying by one hundred. 


\section{Results and Discussion}

From the results of the research that has been carried out, a total of 240 students are divided into five categories, namely very high, high, medium, low and very low, which are presented in the following table.

Tabel 1. Self-Identity $(n=240)$

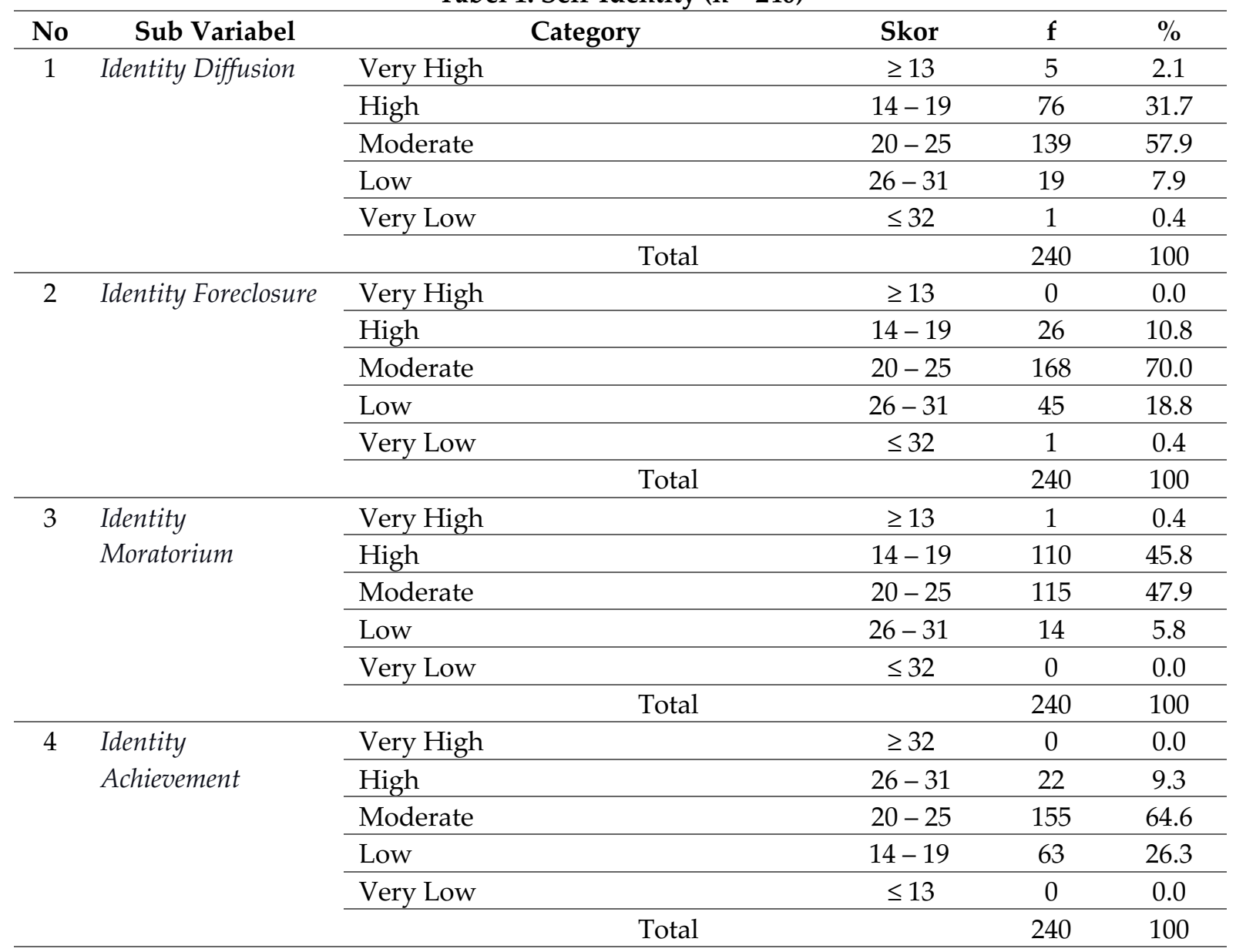

Table 1 above shows that the condition of the identity crisis is in the medium category of $33.8 \%$ (81 students). This shows that there are still students who experience a self-identity crisis. Students who experience an identity crisis are characterized by doubts in exploring and not having a commitment to live their lives (Jordán-Conde, Mennecke, \& Townsend, 2014). Students experience confusion about who they are and confused about what to do with their life. This can allow students to do things that are not in accordance with the norms that apply in the community or their environment.

The next condition, identity dependence is in the high category $10.8 \%$ (26 students). This condition shows that there are still students who depend on other people to do something and in the end their identity is formed by imitating others, because the desires of these students do not come from themselves but from other people (eg parents, teachers and friends). In this condition, it appears that students depend on existing commitments, so they are not interested in exploring to gain new understanding (Jordán-Conde et al., 2014).

Furthermore, the condition of identity confusion is in the high category $46.2 \%$ (111 students). In this condition, it shows that there are still many students who experience confusion over identity. Students doubt their commitment in carrying out daily activities due to the lack of knowledge and understanding of students about themselves. Therefore, students begin to find out from various sources about things 
that can increase their knowledge, both through the media and to teachers at school. So that with this exploration, adolescents will better understand and believe in their commitment to improving their identity. This is in line with the opinion of Nasrudin (2008) which explains that adolescents who are in a condition of identity moratorium view their families ambivalently, namely between wanting to follow their parents' advice and their own desires.

The last condition, namely the attainment of identity, is in the high category $9.3 \%$ (22 students). The results of the need assessment indicate that there are still very few students who achieve their identity. Students who are in an identity achievement condition already have knowledge and understanding of themselves, so that there is an awareness to do something without being affected and will not be easily influenced by others. Exploration carried out by students will produce a commitment in their lives, this condition is called identity achievement (Jordán-Conde et al., 2014). As they get older, adolescents will be more successful in achieving their identity, because they are more able to think rationally and make the right decisions, and have a lot of experience (Suardiman, 2011).

\section{Discussion}

According to Caplan (2014), identity is not a unity, nor is it an essence inherent in the individual, but rather an unstable thing that is unique and has a dynamic relationship that is displayed subjectively and objectively. The formation of self-identity is very important because the task of development at that time is to adapt to the changes that exist in itself. If the formation of his identity is disturbed or is not achieved properly, there will be deviant actions taken by students. In line with the research conducted by Huriati (2016), where adolescents who experience a self-identity crisis tend to do things that violate norms and are not accepted or disliked by society.

Markus (Kettle \& Haubl, 2011) states that self-identity refers to all that is in the self, identity, and schemes that make up the individual. Self-identity requires aspects of exploration and commitment. Exploration shows a period where someone tries to choose a way out of an existing alternative. In life, attitude is something that students must have. Because this will help him to compare himself to other people which in turn will affect their attitude. Meanwhile, commitment is an effort to make decisions and in the end, it will make those decisions happen. Therefore, students are given time to experiment/look for the identity they have before committing to the role or value they choose (JordánConde et al., 2014).

One of the places where students look for / obtain self-identity is at school, therefore the counselor must try to guide and assist students in finding their identity through the services provided. One of the services that can help students identify and improve their identity is the information service provided by the counselor at school. Information services are developed according to students' conditions which can be observed based on the results of the needs analysis. This agrees with Masyita (2018) where the results of his research show that there is a significant influence between information services on students' ability to overcome their identity crisis. Then Ledyana Dwi Situngkir May (2014) also states that there is the influence of the significance of social service delivery information on the handling of the crisis of identity in students.

\section{Conclusion}

Based on the research that has been done, it is found that there are still students who have a high self-identity status in the identity crisis status, identity dependence, identity confusion and there are still a few students who are at high identity attainment status. Therefore, the counselor is needed to help students improve their identity.

\section{References}

Alizamar, A., Afdal, A., \& Ifdil, I. (2017). Guidance and Counseling Services for Kindergarten. Advances in Social Science Education and Humanities Research (ASSEHR). International Conference of Early 
Childhood Education (ICECE 2017), 169, 168-172.

Bailey 2nd, J. A. (2003). Self-image, self-concept, and self-identity revisited. Journal of the National Medical Association, 95(5), 383.

Berdibayeva, S., Garber, A., Ivanov, D., Satybaldina, N., Smatova, K., \& Yelubayeva, M. (2016). Identity Crisis' Resolution Among Psychological Correction of Deviant Behavior of Adolescents. Procedia - Social and Behavioral Sciences, 217, 977-983.

Boonchum. (2009). A Study of Self-Identity Changes and Correlation of Influential Factors of Thai Students Studying English. Academic Journals Educational Research and Review, vol 4(11), 535-548.

Breen, A. (2010). The construction of self-identity and positive behavioural change in pregnant and parenting young women (Doctoral dissertation).

Bridget \& Kriner. (2016). Writer Self-Efficacy and Student Self-Identity in Developmental Writing Classes: A Case Study. Cleveland State University.

Caplan. 2014. Identity and Identification Transcript. Gresham College.

Chen, K. H., Lay, K. L., Wu, Y. C., \& Yao, G. (2007). Adolescent self-identity and mental health: The function of identity importance, identity firmness, and identity discrepancy. 中華心理學刊, 49(1), 53-72.

Cinoglu, H., \& Arikan, Y. (2012) Self, Identity and Identity Formation: From the Perspectives of Three Major Theories. International Journal of Human Sciences, (9)2, 1114-1131.

Dariyo, A. (2004). Psikologi Perkembangan Remaja. Bogor: Ghalia Indonesia.

Fekadu, Z., \& Kraft, P. (2001).Self-identity in planned behavior perspective: past behavior and its moderating effects on self-identity-intention relations. Social Behavior and Personality,29(7), 671686.

Flum, H., \& Kaplan, A. (2012). Identity Formation in Educational Settings: A Contextualized View of Theory and Research in Practice. Contemporary Educational Psychology, 37(3), 240-245.

Glas, G. (2006). Person, Personality, Self, and Identity: A Philosophically Informed Conceptual Analysis. Journal of Personality disorders, 20(2), 126-138.

Guneri, O., Sumer, Z., \& Yildirim, A. (1999). Sources of Self -Identity Among Turkish Adolescents. Journal, Adolescence; 34, 135; Sociology Database.

Hsieh, K. Y., Hsiao, R. C., Yang, Y. H., Lee, K. H., \& Yen, C. F. (2019). Relationship between self-identity confusion and internet addiction among college students: the mediating effects of psychological inflexibility and experiential avoidance. International journal of environmental research and public health, 16(17), 3225.

Huriati, N. H. (2016). Krisis identitas diri pada remaja. Sulesana, 10(1), 49-62.

Jordán-Conde, Z., Mennecke, B., \& Townsend, A. (2014). Late Adolescent Identity Definition and Intimate Disclosure on Facebook. Computers in Human Behavior, 33, 356-366.

Kettle \& Haubl. (2011). The Signature Effect: Signing Influences Consumption-Related Vehavior by Priming Self-Identity. Journal Of Consumer Research, 38, 2011.

Kroger, J., Martinussen, M., \& Marcia, J. E. (2010). Identity stat change during adolescence and young adulthood: A meta-analysis. Journal of Adolescence, 33, 683-698.

Mansfield, Gill \& Golander. (2006). Utilization of Self-Identity Roles for Designing Interventions for Person with Dementia.Journal of Gerontology: Psychological Sciences, 61B, 4, P202-P212.

Masyita, F. (2018). Pengaruh Layanan Informasi Terhadap Kemampuan Siswa Mengatasi Krisis Identitas Diri Di SMA Istiqlal Delitua (Doctoral dissertation, Universitas Islam Negeri Sumatera Utara Medan). Diakses pada Maret 7, 2020, http://repository.uinsu.ac.id/4298/

Nasrudin, E. (2008). Hubungan antara Gaya Pengasuhan Orangtua Tipe Enabling dan Constraining dengan Komitmen dan Pembentukan Status Identitas Keberagamaan Remaja Akhir. Jurnal Psympathic, I(1), 57-66.

Nealy, M. (2013). The Impact of Collectivism on Creative Self-Efficacy in Japanese Learners.

Owens. (2003). Self and Identity. Handbook of Social Psychology. Purdue University, West Lafayette, IN 47907-1365. 
Oyserman, Elmore \& smith. (2012). Self, Self-Concept and Identity. J. Tangney and M. Leary (Eds). The Handbook of Self and Identity, 2nd. Edition, pp 69-104, New York, NY: Guilford Press.

Papalia, D. E., Olds, S. W., \& Feldman,R. D., (2001). Human development. (9 $9^{\text {th }}$ Eds). Terjemahan Oleh Brian Marwensaly. Boston: MsGraw-Hill.

Prasasti, S. (2017). Kenakalan Remaja dan Faktor Penyebabnya. Seminar Nasional Bimbingan dan Konseling, 1(1), 28-45.

Rise, J., Sheeran, P. \& Hukkelberg, S. (2010). The Role of Self-Identity in the Theory of Planned Behavior: A Meta-Analysis. Journal of Applied Social Psychology, 40, 5,pp 1085-1105.

Ross, A. T., Powell, A. M., \& Henriksen Jr, R. C. (2016). Self-identity: A key to Black student success. Ideas and research you can use: VISTAS.

Santrock, J. W. (2007). Remaja Edisi 11 Jilid 1 dan 2. Jakarta: Erlangga.

Simon, B., \& Trötschel, R. (2008). Self and social identity. Introduction to social psychology: A European perspective, 88-110.

Situngkir, L. D. M. (2014). Pengaruh Pemberian Layanan Informasi Bidang Sosial Terhadap Penanganan Krisis Identitas Pada Siswa Kelas XII SMA RK Serdang Murni Lubuk Pakam TA 2014/2015 (Doctoral dissertation, UNIMED). Diakses pada Maret 7, 2020. http://digilib.unimed.ac.id/7834/

Suardiman, S. P. (2011). Psikologi Usia Lanjut. Yogyakarta: Gadjah Mada University Press.

Sudjana, N. (2002). Dasar-dasar Proses Belajar Mengajar. Bandung: Sinar Baru Algensido Offset.

Syarqawi, A. (2015). Identitas Diri Siswa dan Implikasinya Terhadap Layanan Bimbingan dan Konseling. Tesis. Padang: Program Pasca Sarjana UNP.

Tarigan, H. G. (2009). Menulis Sebagai Suatu Keterampilan Berbahasa. Bandung: Angkasa.

Wang, S., Wu, L., \& Lee, S. (2018). Role of Dispositional Aspects of Self-identity in the Process of Planned Behavior of Outbound Travel. Journal of Vacation Marketing, 24(2), 189-199. 